Acta regionalia et environmentalica 1

Nitra, Slovaca Universitas Agriculturae Nitriae, 2013, p. 13-18

\title{
EVALUATION OF FINANCIAL PERFORMANCE OF CONTRIBUTORY ORGANIZATIONS UNDER THE JURISDICTION OF MUNICIPALITIES
}

\author{
Viera PAPCUNOVÁ \\ Constantine the Philosopher University in Nitra, Slovak Republic
}

\begin{abstract}
Public administration reform has brought about, inter alia, the change of financing of original and delegated competences for municipalities. In this context, the conditions for economy of local government have changed, while the pressure was put on municipalities to make more efficient use of their property to receive the greatest possible benefit in terms of economic, social and territorial development. A municipality can manage its own property, but it can also entrust it to the budgetary and contributory organizations. The Act no. 138/1991 Coll. indicates that the municipal authorities and organizations are required to manage municipal property in favour of development of municipalities and their citizens, and protection and creation of the environment. One of the possibilities for increasing the efficiency of property use is also financial analysis, eventually economic analysis. Analysis usually results in practical useful knowledge, creating the foundation for an objective definition of relevant conditions (factors) for the future capital appreciation in municipalities. The aim of this paper is to evaluate financial performance of contributory organizations under the jurisdiction of municipalities with help of selected indicators.
\end{abstract}

Keywords: financial analysis, municipality property, local self - government, contributory organizations

\section{Theoretical background}

According to Act no. 369/1990 Coll. on Municipal establishment, a municipality can use its property mainly for public purposes, the business and the performance of local self-government. Gecíková (2012) ranks proprietary policy of municipality among the most important dynamic factors of municipality development.

In addition to direct business, a municipality can entrust its property to administration of contributory or budgetary organizations, to which it is a founder, according to Act no. $523 / 2004$ Coll. on budgetary rules, as amended, or it can invest it as an input to business company or non-profit organizations.

Contributory organization is a legal entity of a municipality, where less than $50 \%$ of production costs are covered by sales and which is connected to municipal budget by contribution. A municipality can establish contributory organizations to carry out its duties. A municipality cannot establish them in order to perform its decision-making powers.

Financial relations given by a municipality as a founder of its budget are valid for contributory organizations. They can carry out business activities in addition to the main occupation which is ensuring the public welfare services. It is managed according to its budgetary costs, revenues, and economic result. Its budget includes the contribution from the budget founder, and funds received from other entities. Contributory organization pays the cost of operation, repair and maintenance of fixed assets, as well as the acquisition of tangible and intangible property from its own resources and contributions from municipality, while using its own funds preferentially.

The community offers a contributory organization contribution to its operations in such an amount that its budget is generally balanced. Operating aid may also be used to cover depreciation, up to the amount determined by municipality. When the own funds for the acquisition of tangible and intangible property do not cover the needs of contributory organization, municipality as its founder determines the amount of contribution to the acquisition of the designated specific tangible and intangible property. Contributory organization prepares balance of its financial relations with the municipal budget in the end of an economic year.

Having the consent of municipality as its founder, contributory organization can perform business beyond the main activity for which it was established, only if it fulfills tasks given by the founder. The business costs must be covered by the produced revenues.

The funds resulting from that business organization are used for improvement of the provided services (Kollárik, 2000).

Municipalities in the Czech Republic create contributory organizations for cultural institutions (theaters, cinemas) and social institutions to ensure technical services. This follows the Act no. 564/1990 Coll. on State and local selfgovernment, as municipal schools have an obligation to choose this legal form in elementary schools and school facilities (Hrabalová, 2004).

It is very difficult to measure the efficiency of municipal property not only if municipality entrusts it to administration of contributory organizations. In practical decisions of local self-governments, the financial methods of financial or economic analysis in choosing the best variant of government projects or activities are used to a limited extent. In fact, there are still prejudices towards the possibility of measurable demonstration of revenues and costs of different variants of projects, as it is necessary to take into account their public, societal and social character, and also the need to maintain democratic decision-making process. 
In doing so, several authors (Fotr, 1995; Papcunová, Dvorak a Biza, 2006; Papcunová a Balážová, 2006) indicate that results of analysis provide valuable information for certain external entities. These include especially banks. Since municipalities are legal persons, they may as any legal person use also bank loans for their activities. Assessment of indebtedness, liquidity, profitability and other indicators and their development contributes to the image of creditworthiness and constitutes an important basis for determining the credit.

Financial analysis is (Fabbozi and Peterson, 2003) a financial management tool. It consists of the evaluation of financial position and operating performance of the business firm, industry or even the economy and subsequent predictions of future performance and conditions. It is, in other words, exploration of risk and expected return. Analysis can be carried out regularly or occasionally, and not only in order to provide information about investments and financing decisions, but also to assist in implementing personnel policies and reward system as well.

Kameníčková (2003) considers financial analysis a standard tool that is used to assess the financial situation of any entity. It is a tool that provides a comprehensive and detailed view of existing development and what assumptions it creates for future development. It informs about existing trends and potential bottlenecks, which could become obstacles to successful development. It is an important input in decision-making of municipality representatives. It is important for decision-making in a broader sense; from the preparation of the budget to reflection about a bearable amount of debt that would not disturb the stability of public finances and would not significantly restrict the space for such expenses that are necessary for operation of municipality and provide public goods to its inhabitants. Financial department of municipality is its competent authority in the field of financial analysis.

Municipality can make financial analysis:

- 'Ex post' - assesses current and previous financial situation. It reveals the causes of the results obtained.

- 'Ex ante' - forecast of financial and economic results.

Analysis of the financial impact should precede any fundamental choice in the matter of management of municipal property.

Calculation and interpretation of financial indicators belong to financial analysis tools. Financial indicators are defined as numerical characteristics of municipality activities and they are constructed either from items of accounts and data from other sources or from numbers that are derived from them. If these tools are used properly, they can answer many questions regarding the financial health of the reporting entity. Financial indicators can be divided into absolute, differential, ratio and special (Lysoňková, 2006).

Calculation and interpretation of financial proportional indicator is considered essential tool for financial analysis. Proportional indicator is calculated as a ratio of one or more results from financial statements, accounting or budget to another item or group of items (Blaha a Jindřichovská, 1996):

- Generally, the desired properties of indicators according to Kraftová (2002) include: Intelligibility - the construction of indicator should not be too difficult to make it impossible to use the output by management.

- Clarity - indicator should be created in such a way that the output information from the use of indicator does not make it impossible to be used by management.

- Simplicity with sufficient accuracy - for decision-making, it is necessary to divide problem into smaller parts, but coherence has to be preserved as it is often the cause of complexity.

- Significance to the extent that the selected tool and its result conform to a particular goal that is pursued by processed financial analysis.

- Essentiality - financial analysis should not process redundant outputs to avoid incomprehensibility and even more demanding use in management.

From the abovementioned approach it is clear that financial analysis summarizes and evaluates the results for different periods of time and also identifies the factors that influence these results. Based on these results, it predicts future. It is basically a process of interpretation of the past, present and future economic and financial situation of the organization.

The estimation of the effectiveness of municipal management is an essentially impossible task according to Hábová (2001), because the aim of the municipality should be to ensure the comfort and quality of life to its residents. From the view of the nature of public goods is this objective rather a qualitative one and from the point of view of inhabitants also a purely subjective one, because every citizen has different needs and preferences. According to the author, one of the possible measurement methods of qualitative effects is the rating of municipalities, which focuses on whether a municipality will be able to provide the citizens the same or higher level of public goods in the future. Quantitative assessment system is based on an analysis of indicators of income, expenditure and debt.

Currently, in terms of local self-government there are used (although only rarely) mainly two single-criterion methods for comparing inputs and outputs (called inputoutput methods): 'cost benefit analysis' (CBA) and 'cost effectiveness analysis' (CEA).

Input-output models have been used in many empirical studies, where have been analyzed impacts of various decisions on regions. Such authors like Wixted, Yamano and Webb (2006) evaluated the determinants of growth of industrial ecology and sustainable development. Escobedo and Urena (2006) have introduced a new method of regionalization and segmentation with help of these methods, which takes into account the gross value added of each sector in each region and transport infrastructure used in these regions.

Therefore, the regional input - output analysis, using interdisciplinary relationships in the regions are useful tools for regional economic analysis (Regional multipliers, 1997).

\section{Methods}

In the context of self-government decision-making processes, especially in the acquisitions of real estate property by the own investment activities we suggest the 
Table 1 Indicators of financial analysis

\begin{tabular}{|l||l|}
\hline \multirow{3}{*}{ Autarchy indicators } & - main activity autarchy \\
\cline { 2 - 3 } & - business activity autarchy \\
\hline \hline \multirow{4}{*}{ Profitability indicators (2) } & - profitability of business activities costs \\
\cline { 2 - 2 } & - the coverage rate of loss from the main activity by the business profits \\
\cline { 2 - 3 } & - cost-per-cent ratio from business activities incomes in relation to the fracture factor ( $\psi$ ) \\
\cline { 2 - 3 } & - total costs variator \\
\cline { 2 - 3 } & - the rate of creditor risk \\
\cline { 2 - 3 } & - the power of leverage (debt ratio on equity) \\
\hline
\end{tabular}

Source: Kraftová, 2002

Table 2 Input data for the calculation of financial analysis indicators

\begin{tabular}{|l|c|c|c|c|c|c|c|}
\hline mil. $€$ & $\mathbf{2 0 0 3}$ & $\mathbf{2 0 0 4}$ & $\mathbf{2 0 0 5}$ & $\mathbf{2 0 0 6}$ & $\mathbf{2 0 0 7}$ & $\mathbf{2 0 0 8}$ & $\mathbf{2 0 0 9}$ \\
\hline Total costs of the main activity & 201 & 186 & 177 & 167 & 153 & 158 & 167 \\
\hline Total revenues from the main activity & 192 & 177 & 177 & 166 & 147 & 155 & 167 \\
\hline Profit from the main activity after tax & -8 & -8 & -0.17 & -0.63 & -5.44 & 2.22 & -0.28 \\
\hline Total costs of business activities & 54 & 44 & 47 & 43 & 28 & 24 & 19 \\
\hline Total revenues from business activities & 53 & 45 & 47 & 44 & 28 & 24 & 20 \\
\hline $\begin{array}{l}\text { Economics results of business activities after } \\
\text { taxation }\end{array}$ & -0.03 & 0.83 & 0.20 & 1.06 & 0.8 & 0.43 & 0.69 \\
\hline Total costs & 255 & 230 & 224 & 210 & 180 & 182 & 187 \\
\hline Total revenues & 246 & 222 & 224 & 211 & 176 & 180 & 188 \\
\hline
\end{tabular}

Source: Datacentrum, own processing

possibility of using the input-output methods, applications of which aim to measurably demonstrate what are the costs and benefits of different decision options. Financial analysis can also serve as an inspiration and argument to the upcoming or already taken decision.

Financial analysis can serve to municipal council primarily as an argument for upcoming decisions on the use of municipal property, and its findings can also serve as arguments for obtaining public support as they represent a proof of correctness of the taken decisions. The methods used by financial analysis aim to measurably demonstrate what are the costs and benefits of different decision options.

The sources for financial analysis are accounting statements - balance sheet, profit and loss account, statement of cash flows.

The essence of financial analysis is a calculation of financial - economic indicators by which it is possible to assess effectiveness.

There are currently no specifically defined indicators of financial analysis at the municipal level in the Slovak Republic. However and Kraft (2002) in her publication lists some indicators of financial analysis, according to which it is possible to evaluate the efficiency of municipal property. Therefore, we selected the indicators used for the evaluation of the financial performance of subsidized organizations which municipalities can entrust to manage their assets. Financial performance was evaluated in the time series from 2003 to 2009.

As a source for input information for the calculation of partial indicators, we used information from Datacenter, which is under direct management competence of Ministry of Finance. These aggregated data are for all municipalities in Slovakia. These data are part of the final accounts of public administration in the Slovak Republic. The municipalities enter the data into the Datacenter annually through statistical summaries.

\section{Results}

\section{Autarchy indicators}

Autarchy means economic and financial self-sufficiency. This implies that the indicators reflect the level of financial and economic self-sufficiency.

Main activity autarchy:

$$
A_{M A}=\frac{\text { revenue from main activity }}{\text { cost on main activity }} \times 100 \%
$$

This indicator reflects the degree of self-sufficiency in terms of coverage of the costs of the main activities from revenues obtained from the main activity. It is reported as a percentage. It is positively evaluated if the value of the indicator reaches at least $100 \%$. In the case that the value is less than $100 \%$, the coverage of the costs by revenues is insufficient.

Figure 1 shows that contributory organizations established by municipalities were financially and economically self-sufficient only in the years 2005 and 2009, because main activity autarchy was at the level of $100 \%$ 


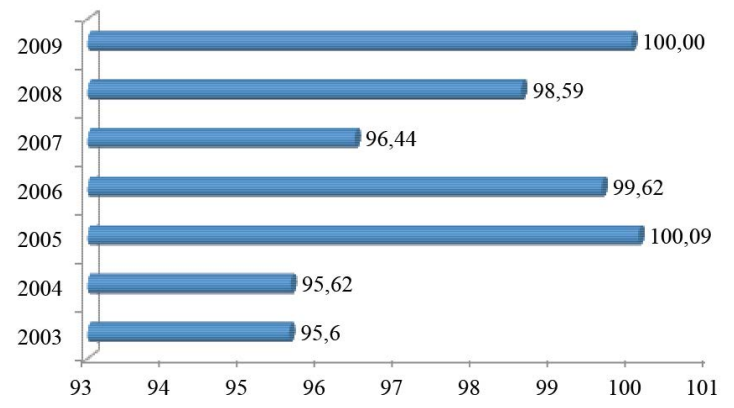

Figure 1 Development of main activity autarchy based on revenues and costs in \%

Source: Datacentrum, own processing

and more. In the other years, contributory organizations were not able to cover the costs incurred from revenues received from the main activity. This fact is the reason why contributory organizations should also perform business activities.

To determine whether these organizations are able to cover the costs of business activities by revenues from such activities, we also calculated the autarchy of business acitivites.

Business activity autarchy:

$$
A_{B}=\frac{\text { business income }}{\text { cost on business }} \times 100 \%
$$

This indicator reflects the degree of self-sufficiency in terms of coverage of the costs of business activities by respective revenues. It is positively evaluated if the value of the indicator reaches at least $100 \%$. In the case the value is less than $100 \%$, the costs are not sufficiently covered by the revenues.



Figure 2 Development of business activities autarchy based on revenues and costs in \%

Source: Datacentrum, own processing

Evaluating business activities, we found out that contributory organizations were unable to cover the cost of business by relevant revenues only in 2003. In further years, the situation has been much more favourable.

\section{Profitability indicators}

Profitability indicators belong to classical indicators for evaluating the effectiveness of businesses. However, in contributory organizations established by municipalities, this concept is very questionable. Profitability presents the ability to create higher revenues than the costs associated with achieving these revenues, so this is essentially a company's ability to generate profits. This way, we could define it in case of a company whose primary objective is to produce profits. However, the situation is different in organizations established by municipalities. The primary objective of such organizations is provision of public services to the residents of municipalities, and only then making profits.

Profitability of business activity:

$$
P_{B C}=\frac{\text { economic results of business }}{\text { cost on business }} \times 100 \%
$$

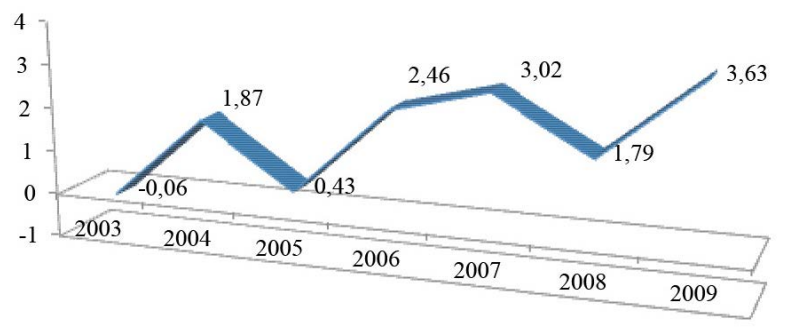

Figure 3 The development of business activities costs profitability in \%

Source: Datacentrum, own processing

From the development of the indicator it is clear to us that contributory organizations marked a very low cost profitability in the operation of their business activities. In 2003 , it even became negative $-0.06 \%$. Since 2004 , it has started reaching positive values; the highest profitability of contributory organizations was achieved in 2009, when they created costs of $€ 1$ per $€ 3.63$ of profits. The results of the indicator raise the question whether the business activities carried out by contributory organizations beyond the main activities are effective in terms of profitability.

The coverage rate of loss from the main activity by the business profits:

$$
M_{C L}=\frac{\begin{array}{c}
\text { economic results of business } \\
\text { implicit in the positive value }
\end{array}}{\text { economic results of main activity }} \times 100 \%
$$

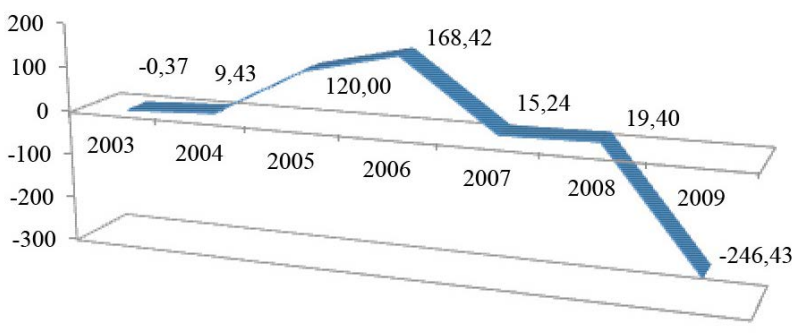

Figure 4 Development of the coverage rate of loss from the main activity by business activities profits in $\%$ Source: Datacentrum, own processing 
The Figure 4 implies that the development of the coverage rate of loss from the main activity by profits from business activities in moniored period had variable character. In the years 2003, 2004 and 2007, the loss from the main activities of the contributory organization was not covered by the profit from business activities. In 2009, the loss from the main activities was covered by the profits from business activity.

\section{Cost-per-cent ratio from business activities incomes in relation to the fracture factor $(\psi)$}

Cost-per-cent ratio $(\psi)$ captures the degree of costs fixation per $1 €$ of income. In order to increase efficiency, it should reach the lowest possible value. Kraftová (2002) states that the fracture value is $\psi=0.6180339$. The more the cost-percent indicator approaches the fracture factor, the better the economic outcome of entrepreneurial activity:

$$
\psi=\frac{\text { cost on business }}{\text { income from business }}
$$

Cost-per-cent ratio of revenues from the business activities each year highly exceeds the fracture factor (see Figure 5). It means that the rate of fixation of costs in the analyzed period was moving between the levels of 0.95 and $1 €$ per $1 €$ of revenues, which in terms of the indicator shows the low efficiency of business activities carried out by contributory organizations. If these organizations carry out business activities in the future, revision of the business activities or reducing their costs and increasing revenues should be introduced, so as to reduce the level of fixation costs per produced revenues.

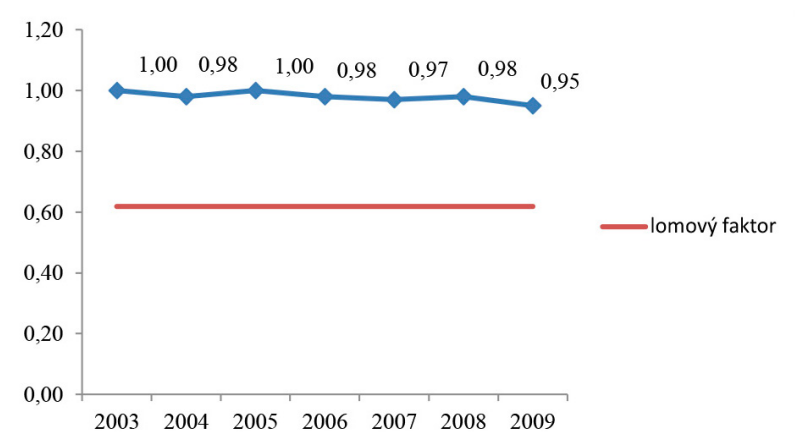

Figure 5 Cost-per-cent indicator development in $€$ Source: Datacentrum, own processing

\section{Total costs variator}

This indicator captures the relationship between the dynamics of the total costs of development and dynamics of development of total revenues in a given period. According to Kraftová (2002), if the variator value is bigger than 1, it means stronger dynamics of costs increase. In this case, it is necessary to look for additional income e.g. to increase fees for provided services, or look for cost savings. If the variator is less than 1, it is possible to expand the business or reduce fees for provided services.

$$
\operatorname{Var}_{T C}=\frac{\frac{T C_{t+1}-T C_{t}}{T C_{t}}}{\frac{T R_{t+1}-T C_{t}}{T C_{t}}}
$$

where:

$T C_{t+1}-$ total costs for the period $t+1$

$T_{C t} \quad$ - total costs for the period $t$

$T R_{t+1}-$ total revenues in the period $t+1$

$T R_{t} \quad-$ total revenues in the period $t$

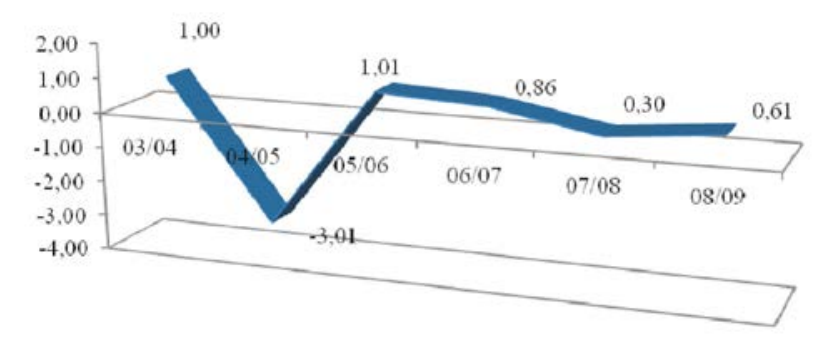

Figure 6 Development of total costs variator

Source: Datacentrum, own processing

From the development of variator it is clear that the value less than 1 was recorded in 2004 and 2005. Variator reached the value -3.01 , which means that the total costs grew more slowly in this period than the total revenues of contributory organizations. In the following monitored periods, the variator reached the value 1 , resp. 1.01, with the exception of the years 2006-2007, 2007-2008 and 2008-2009 when it reached the value in range from 0.30 to 0.86 . Kraftová (2002) in her publications does not present the situation in which variator is equal to 1 , but it can be concluded that if a variator is equal to 1 , the dynamics of the total costs equals total revenues dynamics. In view of the dynamics of the total costs and benefits, we can observe a slight improvement in 2007 and 2008 when the variator reached the value 0.30 , which means that in this case, total revenues grew faster than total costs.

\section{Conclusion}

On the base of financial performance evaluation of contributory organizations established by municipalities we reached following conclusions:

- The loss of the main activities was not covered by profits from business activities in 2003, 2004, 2007.

- In 2009, the loss of the main activities was covered by the profits of the business activities.

- In terms of profitability, contributory organizations showed a very low cost profitability of business activities in the observed period (max. they reached in year 2009 when per $€ 1$ of costs they managed to create $a € 3.63$ of profit).

- The fixation costs rate for business activities ranged from $€$ 0.95 to $€ 1$ per $€ 1$ of revenues.

- Dynamics of the total costs was equal to the dynamics of total revenues only in the years 2003-2004 and 2005-2006.

The importance of financial performance assessment lies primarily in being able to quantify the economic phenomena and then assess their quality and economic activities and their results.

Although we were able to assess management of contributory organizations in the municipalities by using indicators for financial performance evaluation, it should be noted that it is not possible to generalize the statements on 
the base of achieved results, but it is necessary to interpret the partial indicators very cautiously due to specificity of the entities that were evaluated.

\section{References}

BLAHA, Z. S. - JINDŘICHOVSkÁ, I. 1996. Jak posoudit finanční zdraví firmy. 2. doplnené vyd. Praha : Management Press, 1996. 159 s. ISBN 80-85603-80-2.

ESCOBEDO, F. - URENA, J. M. 2006. The Influence of Transport Links on Disaggregation and Regionalization Methods in Interregional Input-Output Models Between Metropolitan and Remote Areas. Paper Presented in the International Conference on Mathematical and Statistical Modeling in Honor or Enrique Castillo. June 28-30, 2006.

FABBOZI, F. J. - PETERSON, P. P. 2003. Financial management and analysis. USA : New Jersey, 2003, 1022 p. ISBN 0-471-23484-2

FOTR, J. 1995. Computer Supported Financial Analysis of the Firms. In: Czech Journal of Economics and Finance, vol. 45, 1995, no. 6, p. 317-326

GECÍKOVÁ, I. 2012. Postavenie miestnej samosprávy pri poskytovaní a zabezpečovaní a zabezpečovaní infraštruktúry v obciach. In: Paradigmy budúcich zmien v 21.storočí. Infraštruktúra spoločnosti. Infraštruktúra človeka. Kontrolovaná spoločnost'. Zborník statí. Bratislava: SAV, 2012. s. 162-173. ISBN 978-80-7144-198-4

HÁBOVÁ, M. 2001. Sektorová analýza hospodáření http://denik. obce.cz/go/clanek.asp?id=215131

HRABALOVÁ, S. 2004. Teorie a praxe rozvoje měst a obcí. Brno : Masarykova univerzita, 2004, 93 s. ISBN 80-210-3356-8

KAMENÍČKOVÁ. 2003. Je finanční analýza nutná? http://denik. obce.cz/go/clanek.asp?id=23356
KRAFTOVÁ, I. 2002. Finanční analýza municipální firmy. 1. vyd., Praha: C. H. Beck, 206 s. ISBN 80-7179-778-2.

KOLLÁRIK, L'. 2000. Postavenie obce k ostatným podnikatel'ským subjektom. In: Územná samospráva v praxi. Bratislava, 2000, s. 5-21. ISSN 1335 - 5937.

LYSOŇKOVÁ, M. 2006. Finanční analýzy při řízení města. Brno: Masarykova univerzita, 2006, $78 \mathrm{~s}$.

PAPCUNOVÁ, V. - BALÁŽOVÁ, E. 2006. Majetok obcí. 1. vyd. Nitra : Slovenská akadémia pôdohospodárskych vied, 2006, $123 \mathrm{~s}$. ISBN 80-89162-19-3

PAPCUNOVÁ, V. - DVOŘÁK, M. - BIZA, J. 2006. Ex post analýza majetkovej štruktúry a zdrojov krytia majetku obcí v SR. In: Současné problémy rozvoje regionů a př́stup veřejné správy $\mathrm{k}$ jejich řešení: sborník referátů z III. mezinárodní vědecké konference mladých vědeckých pracovníků a doktorandů, Brno 24.-26. května 2006. Brno : Masarykova univerzita, 2006, s. 228-235. ISBN 80-210-4148-X.

REGIONAL MULTIPLIERS. 1997. http://www.bea.gov/scb/pdf/ regional/perinc/meth/rims2.pdf

WIXTED, B. - YAMANO, N. - WEBB, C. 2006. Input-Output Analysis in an Increasingly Globalised World: Applications of OECD's Harmonised International Tables. OECD STI Working Papers, Paris : OECD, 2006, no. 7.

\section{Contact address:}

doc. Ing. Viera Papcunová, PhD., Institute of Management and Information Technologies, Faculty of Natural Sciences, Constantine the Philosopher University in Nitra, Tr. A. Hlinku 1, 94974 Nitra, Slovak Republic, e-mail: vpapcunova@ukf.sk 